\title{
わが国の緩和ケア病棟における看護師の ターミナルケア態度に関連する要因
}

\author{
高野 純子1), 山花 令子2), 山本 則子 ${ }^{3)}$ \\ 1）一般財団法人同友会藤沢湘南台病院 看護部, 2) 東京医療保健大学 千葉看護学部, \\ 3) 東京大学大学院医学系研究科 健康科学. 看護学専攻
}

【目的】全国の緩和ケア病棟における看護師のターミナルケア態度の関連要因を明らかにする.【方法】病棟看護管理者 103 名, 看護師 1,671 名への自記式質問紙調査. 【結果】看護管理者 93 名, 看護師 1,112 名(有効回答率 90.3, $66.5 \%)$ を分析. ターミナルケア態度の下位尺度の死にゆく患者へのケアの前向きさ, 患者·家族中心のケアの認識 の高さは緩和ケア病棟への配属希望 $(\beta=0.159, \beta=0.131, p<0.01)$ が関連した. ケアの前向きさは, 緩和ケア病棟 経験年数 $(\beta=0.125, p<0.01)$, 基本的緩和ケアの研修の修了 $(\beta=0.065, p<0.05)$ 等 10 因子, 認識の高さは, 患者 . 家族の創作活動支援 $(\beta=0.114, p<0.01)$ 等 4 つが関連した.【結論】前向きなターミナルケア態度を涵養するための, 基本を礎にした経験の蓄積と支持的教育，充実した緩和ケア病棟体制の重要性が示唆された.

Palliat Care Res 2018; 13(4): 357-66

Key words: ターミナルケア態度, 緩和ケア病棟, 看護師

\section{緒 言}

わが国のがん罹患数および死亡数が増加する中 ${ }^{1)}$, がん患者の 3〜4 割は苦痛緩和が十分でないという報 告もあり ${ }^{2}$, さらなるがん対策推進基本計画が進行中 である ${ }^{3)}$. 対策の一つである緩和ケアは一般病棟等で 提供される基本的緩和ケアと, 一般病棟では対応が困 難ながん終末期の複雑な症状や問題をもつ患者・家族 の生活の質を高める専門的緩和ケアがあり，緩和ケア チームや緩和ケア病棟, 在宅緩和ケアで提供される ${ }^{4)}$. 近年, 緩和ケア病棟は, 在院期間の短縮化や, 在宅療 養支援のためのバックベッド機能など，その役割は変 化 ${ }^{5)}$, 従来の看取り型と, 看取りも行うが症状緩和 後は早期退院を促す急性期型に分かれ始めている。ま た, 2017 年現在, 緩和ケア病棟入院料届出受理施設数 は386 施設まで増加した ${ }^{6)}$ が, 施設により専門的緩和 ケアの質が異なり，施設評価の仕組み作りが始まって いる7).

緩和ケア病棟の看護師は, 短期化する在院期間で患 者・家族の意思決定支援や退院支援, ターミナルケア

受付日 2018 年 6 月 20 日 / 改訂日 2018 年 9 月 28 日 / 受理日 2018 年 10 月 1 日

\footnotetext{
Corresponding Author：高野純子

一般財団法人同友会 藤沢湘南台病院 看護部

干 252-0802 神奈川県藤沢市高倉 2345

TEL 0466-44-1451 FAX 0466-44-6771

E-mail: jtakano-tky@umin.ac.jp
}

を実践するなど多様な役割を担う。一方で，多くの患 者が死亡する緩和ケア病棟では，看護師は心身に影響 を受( ${ }^{8)}$ ，看護師自身がセルフケアを行い，患者の死 に真摰に向き合う必要がある。また，わが国のがん患 者の遺族調査で, 緩和ケア病棟の医療従事者との関わ りが遺族にとり心に深く残る体験だったことが示され ており ${ }^{9)}$, 患者・家族に直接関わる看護師の態度は専 門的緩和ケアの質を左右するといえる.

このような看護師の前向きなターミナルケア態度 は, がん診療連携拠点病院, 訪問看護師や高齢者ケア 施設等で年歯, 臨床経験年数, 身近な人の看取り経 験, 看取りケアへの満足感等との関連について報告が あるが10 13), 年齢や臨床経験等は関連がなかった報告 もある ${ }^{14)}$ 。また, 看取りの多い緩和ケア病棟で調査す ることで影響要因がより明確になると考えるが, こう した調査は見当たらない.

そこで本研究の目的は, 全国の緩和ケア病棟の看護 師を対象に, 患者・家族に直接関わる看護師のターミ ナルケア態度を調査し, 前向きなターミナルケア態度 に影響する個人因子や施設因子を明らかにすることに ある. 緩和ケア病棟は, 多職種チームが基盤であり, 職場環境や専門的緩和ケアの内容は看護師の態度に影 響し，これまでにない全国の多様な地域にある緩和ケ ア病棟の看護師の調査によって組織因子を明らかにで きると考える。これらの要因から, 緩和ケア病棟にお いて患者・家族への質の高いケアにつながる看護師の 前向きなターミナルケア態度を身につけるための教育 
や職場環境である病棟組織でも専門的緩和ケアの実践 上で有用な示唆を得ると考える。

\section{方 法}

\section{研究デザイン}

無記名自記式質問紙による横断研究である.

\section{対象者}

国立がん研究センターがん情報サービス ${ }^{15)}$ ，日本ホ スピス緩和ケア協会6)による公開情報から全国の緩和 ケア病棟入院料届出受理施設 386 施設 (2017 年 10 月現 在)のリストを作成し, 調査協力に応じた 103 施設, 看 護師 1,671 名を対象とした。

\section{データ収集}

施設看護管理者の協力の意思表示が得られた施設 に，研究説明書，事前に尋ねた人数分の看護師用質問 紙，緩和ケア病棟看護管理者用 (以後, 看護管理者) 質 問紙，質問紙用封筒，および一括返送用封筒を郵送 し，2 週間を目途に郵送法にて回収した。調査期間は 2017 年 10 月から 11 月だった。

\section{調查項目}

\section{1. 個人因子}

性別，年齢，看護系の最終教育機関，看護系教育機 関での緩和ケアの授業経験，看護師経験年数，緩和ケ ア病棟経験年数, 過去の専門的緩和ケアの経験, 職 位, 緩和ケア病棟への配属希望, The End-of-Life Nursing Education Consortium Japan version(ELNEC-Jコアカリ キュラム看護師教育プログラム : 以下, ELNEC-J) ${ }^{16)}$ 修 了の有無, ELNEC-J 指導者資格 (ELNEC-J を指導する 資格)の有無，6力月間で専門書・雑誌を閲読した冊 数，がん・緩和ケア分野の専門資格等を尋ねた。管理 者でない専門資格者は直接ケアを実践している場合が 多いため, 対象に含めた。

ELNEC は，米国のアメリカ看護大学協会と City of Hope 国立医療センターによる組織で, 系統的な Endof-Life care の基本的緩和ケアの教育プログラムを開発 し ${ }^{17)}$ ，日本版修了者は 29,000 人以上となった (2018 年 現在) ${ }^{18)}$.

\section{2. 組織因子}

緩和ケア病棟で患者・家族に直接関わる看護師の態 度を分析するため，看護管理者へは組織背景を尋ね， その回答を看護師の個人属性の組織因子とした。調査 項目は，施設病床数. 緩和ケア病棟設立からの年数. 通算看護経験 1 年目の看護師の緩和ケア病棟への配 置. 病棟に打けるがん・緩和ケア分野の資格者の存 在, 他職種。デスケースカンファレンス開催頻度。提 供している専門的緩和ケアの内容。緩和ケア病棟で取 り入れている教育方法だった。

\section{3. ターミナルケア態度}

Frommelt attitudes toward care of the dying scale $の$ FATCOD-Form B-J (Frommelt のターミナルケア態度尺 度日本語版 ${ }^{19)}$ を使用した (付録図参照)。この尺度は, 米国の Frommelt が開発した死にゆく患者に対する医 療者のケア態度の測定の ${ }^{20)} の$ 日本語版であり，信頼性 と妥当性が確認されている。 30 項目について,「非常 にそう思う」「そう思う」「どちらともいえない」「そう思 わない」「全くそうは思わない」の 5 件法で評価する。 3 つの下位尺度があり, 《死にゆく患者へのケアの前向 きさ》16〜80 点, 《患者・家族を中心とするケアの認 識》13〜65 点で, ターミナルケア態度の得点が高いほ ど，より前向きな態度，患者・家族中心のケアの認識 が高いことを示す。なお，三つ目の《死の考え方》は項 目数が一つと限定され, 独立した下位尺度として活用 しないことが推奨されているため除外し，29項目の二 つの下位尺度を分析した。

4. 分析

個人属性について記述統計量を算出し回答分布を確 認した。単変量解析として, 看護師の個人属性とター ミナルケア態度の二つの下位尺度間で, 2 值変数は $\mathrm{t}$ 検 定を実施し, 連続変数はSpearmanの順位相関係数を算 出した。その後, ターミナルケア態度のうち《死にゆく 患者へのケアの前向きさ》《患者・家族を中心とするケ アの認識》に関連する個人属性を検討するために，従 属変数をターミナルケア態度尺度の二つの下位尺度と し，下位尺度ごとに単変量解析で $\mathrm{p}<0.20$ だった個人因 子の変数を説明変数として投入し, Stepwise 法にて重 回帰分析を行った。有意水準は, $\mathrm{p}<0.05$ (両側検定) と し, 統計処理には統計解析ソフト SAS University Edition Version 3.6, Basic Editionを使用した。

5. 倫理的配慮

本研究に先立ち, 東京大学医学部倫理審査委員会の 承認を得た。対象者の調査説明書に, 参加の任意性, 個人情報保護等を明記し, 質問紙の返送をもって調査 への同意が得られたとみなした。

\section{結 果}

38 都道府県 99 施設, 看護管理者 93 名 (回収率 $90.3 \%$ ), 看護師 1,223 名 (回収率 $73.2 \%$ ) から回収した. そのうち, 回答の $20 \%$ 以上の久損, 尺度の下位項目で 半数以上の欠損等があった 111 名を除外し，分析対象 は看護管理者 93 名, 看護師 1,112 名 (有効回答率 $90.3 \%$ ，66.5\%)だった。

\section{対象者の属性 (表 1)}

女性が $96.1 \%$ を占め, 看護経験年数は $16.1 \pm 8.2$ 年 だった。緩和ケア病棟勤務平均年数 $3.7 \pm 3.0$ 年, 緩和ケ 


\begin{tabular}{|c|c|c|c|c|c|}
\hline & $\begin{array}{c}\operatorname{mean} \pm \mathrm{SD}^{1)} \\
\mathrm{n}(\%)\end{array}$ & $\mathrm{n}$ & & $\underset{\mathrm{n}(\%)}{\operatorname{mean} \pm \mathrm{SD}}$ & $\mathrm{n}$ \\
\hline $\begin{array}{l}\text { 個人因子 } \\
\text { 性別 }\end{array}$ & & & $\begin{array}{l}\text { 組織因子 } \\
\text { 施設病床数 }\end{array}$ & & \\
\hline 女性 & $1069(96.1)$ & 1112 & 199 床以下 & $376(33.8)$ & 1112 \\
\hline 年齢 & $40.6 \pm 9.1$ & 1104 & 200 床以上 & $736(66.2)$ & \\
\hline 看護系の最終教育機関(学歴) & & & 緩和ケア病棟設立からの年数 & $8.8 \pm 5.8$ & 1112 \\
\hline 短大以上 & $180(16.3)$ & 1104 & 3 年未満 & $261(23.5)$ & 1112 \\
\hline その他2) & $924(83.7)$ & & 3 年以上 & $851(76.5)$ & \\
\hline 看護系教育機関での緩和ケアの授業経験 & & & 緩和ケア病棟にがん性疼痛認定看護師 & & \\
\hline なし & $580(54.4)$ & 1066 & あり & $204(23.7)$ & 859 \\
\hline あり & $486(45.6)$ & & 緩和ケア病棟に緩和ケア認定看護師 & & \\
\hline 看護経験年数 & $16.1 \pm 8.2$ & 1112 & あり & $782(89.9)$ & 870 \\
\hline 緩和ケア病棟勤務年数 & $3.7 \pm 3.0$ & 1112 & 緩和ケア病棟にがん専門看護師 & & \\
\hline 1,2 年目 & $503(45.2)$ & 1112 & あり & $113(13.2)$ & 857 \\
\hline $3,4,5$ 年目 & $389(35.0)$ & & 通算看護経験 1 年目の看護師の配置 & & \\
\hline 6 年目以上 & $220(19.8)$ & & あり & $113(11.0)$ & 1023 \\
\hline 過去の専門的緩和ケアの経験3) & & & 緩和ケア病棟に宗教者5) & & \\
\hline なし & $601(54.0)$ & 1112 & あり & $202(19.5)$ & 1034 \\
\hline あり & $511(46.0)$ & & 緩和ケア病棟に理学療法士 ${ }^{5)}$ & & \\
\hline 他の緩和ケア病棟経験 & & & あり & $721(69.7)$ & 1034 \\
\hline $\begin{array}{l}\text { あり } \\
\text { 在宅緩和ケア経験 }\end{array}$ & $128(11.5)$ & 1109 & $\begin{array}{l}\text { 緩和ケア病棟にボランティアコーディ } \\
\text { ネーター5) }\end{array}$ & & \\
\hline あり & $59(5.3)$ & 1111 & あり ～～～～～～～ & $365(42.9)$ & 850 \\
\hline 緩和ケアチーム経験 & & & デスケースカンファレンスの開催 & & \\
\hline あり & $362(32.6)$ & 1111 & 不定期 & $522(51.4)$ & 1015 \\
\hline 職位 & & & 定期 & $493(48.6)$ & \\
\hline なし & $959(87.5)$ & 1096 & 提供している専門的緩和ケアの内容 & & \\
\hline あり & $137(12.5)$ & & ベッドごとの散歩 & & \\
\hline 緩和ケア病棟への配属希望 & & & あり & $808(78.1)$ & 1034 \\
\hline 希望なし & $447(41.1)$ & 1088 & 患者·家族の創作活動の支援 & & \\
\hline 希望あり & $641(58.9)$ & & あり & $479(46.3)$ & 1034 \\
\hline ELNEC-J' ${ }^{4)}$ の修了 & & & ボランティアによる花の水替え & & \\
\hline なし & $518(46.7)$ & 1109 & あり & $559(54.1)$ & 1034 \\
\hline あり & $591(53.3)$ & & ボランティアによる搽のサービス & & \\
\hline ELNEC-J ${ }^{4}$ 指導者資格 & & & あり & $644(62.3)$ & 1034 \\
\hline $\begin{array}{l}\text { なし } \\
\text { あり }\end{array}$ & $\begin{array}{c}1063(96.1) \\
43(3.9)\end{array}$ & 1106 & $\begin{array}{l}\text { 緩和ケア病棟で取り入れている教育方法 } \\
\text { 独自の教育プログラム }\end{array}$ & & \\
\hline $\begin{array}{l}6 \text { カ月間で専門書・雑誌を閲読した冊数 } \\
\text { 専門誌などからの知見の臨床への活用頻 }\end{array}$ & $3.2 \pm 3.6$ & 1064 & $\begin{array}{l}\text { あり } \\
\text { 事例検討会 }\end{array}$ & $639(63.2)$ & 1011 \\
\hline 度 & & & あり & $832(80.5)$ & 1034 \\
\hline 低い & $648(59.0)$ & 1098 & 院内外の講義·講演への参加 & & \\
\hline 高い & $450(41.0)$ & & あり & $1016(98.3)$ & 1034 \\
\hline \multicolumn{6}{|l|}{ がん・緩和ケア分野の専門資格 } \\
\hline なし & $1042(93.7)$ & 1112 & & & \\
\hline あり & $70(6.3)$ & & & & \\
\hline
\end{tabular}

1) SD : Standard Deviation

2) その他：高等学校, 高等学校専攻科, 専門・専修を含む

3）他の緩和ケア病棟, 緩和ケアチーム, 在宅緩和ケアの複数経験を含む

4）ELNEC-J : The End-of-Life Nursing Education Consortium Japanese version コアカリキュラム看護師教育カリキュラムの略称で, 基本的 緩和ケアの看護師教育プログラム

5）各職種については，緩和ケア病棟との兼任，非常勤勤務を含める 
ア病棟での 1,2 年目は $45.2 \%, 3 \sim 5$ 年目は $35.0 \%$ だっ た。過去の専門的緩和ケアの経験ありは $46 \%$ だった。 役職者(主任以上管理者未満) は $12.5 \%$ (役職者のみで は, 看護経験平均年数 $21.5 \pm 6.3$ 年, 緩和ケア病棟経験 $5.2 \pm 4.1$ 年, 専門資格あり $20.4 \%)$ で，専門資格者は $6.3 \%$ だっ。緩和ケア病棟は設立から平均 $8.8 \pm 5.8$ 年 だった。

ターミナルケア態度の両下位尺度の得点は, 《死に ゆく患者へのケアの前向きさ》は平均 $62.8 \pm 7.4$, 《患 者・家族を中心とするケアの認識》は平均 $50.1 \pm 4.9$ だっ た $(\mathrm{n}=1,112)$.

\section{ターミナルケア態度の下位尺度に関連する要因}

1. 単変量解析の結果 (表 2)

ターミナルケア態度の両下位尺度《死にゆく患者へ のケアの前向きさ》(以下, 前向きな態度), 《患者・家 族を中心とするケアの認識》(以下，ケアの認識の高 さ）に関連した要因は, 看護系教育機関での緩和ケア の授業経験 (前向きな態度; $\mathrm{p}<0.01$, ケアの認識の高さ; $\mathrm{p}<0.05)$, 職位 (主任以上) $(\mathrm{p}<0.01)$, 緩和ケア病棟への 配属希望者 $(\mathrm{p}<0.01) ，$ ELNEC-J の修了（前向きな態度； $\mathrm{p}<0.01$ ，ケアの認識の高さ; $\mathrm{p}<0.05), 6$ 力月間で専門 書・雑誌を閲覧した冊数の多さ (前向きな態度; $\rho=0.256 \mathrm{p}<0.01$, ケアの認識の高さ; $\rho=0.104 \mathrm{p}<0.01)$, 専門誌からの知見の臨床への活用頻度の高さ $(\mathrm{p}<$ 0.01 ), がん・緩和ケア分野の専門資格者(前向きな態 度 $; \mathrm{p}<0.01$, ケアの認識の高さ; $<<0.05)$, 患者・家族の 創作活動支援 $(\mathrm{p}<0.05)$ たっった。

《前向きな態度》にのみ関連した要因は，女性 $(\mathrm{p}<$ $0.01)$, 年歯 $(\rho=0.109 \mathrm{p}<0.01)$, 学歴 (短大以上) $(\mathrm{p}<0.05)$, 看護経験年数 $(\rho=0.102 p<0.01)$, 緩和ケア病棟勤務年数 $(\rho=0.208 \mathrm{p}<0.01)$, 他の緩和ケア病棟の経験あり $(\mathrm{p}<$ $0.01)$ ， ELNEC-J 指導者資格 $(\mathrm{p}<0.01)$ ，病棟に宗教者あ り $(\mathrm{p}<0.01)$, 病棟に理学療法士あり $(\mathrm{p}<0.05)$, 病棟にボ ランティアコーディネーターあり $(\mathrm{p}<0.05)$ だった。 ま た，緩和ケア病棟で提供するケアとしてベッドごとの 散歩あり $(\mathrm{p}<0.01)$ ，ボランティアによる花の水替えあ り $(\mathrm{p}<0.01)$ ， ボランティアによるお茶のサービスあり $(\mathrm{p}<0.05)$, 緩和ケア病棟で取り入れている教育方法で は，緩和ケア病棟独自の教育プログラムあり $(\mathrm{p}<0.01)$, 事例検討会あり $(\mathrm{p}<0.05)$, 院内外の講義・講 演への参加あり $(\mathrm{p}<0.01)$ も関連した。

《ケアの認識の高さ》のみに関連したのは, 緩和ケア 病棟設立からの年数が 3 年未満 $(\mathrm{p}<0.01)$, 病棟に緩和 ケア認定看護師あり $(\mathrm{p}<0.01)$, 通算看護経験 1 年目の 看護師の配置あり $(\mathrm{p}<0.05)$ だった。

2. 多変量解析の結果 (表 3)

ターミナルケア態度の両下位尺度に関連した看護師 の要因は, 緩和ケア病棟への配属希望あり（前向きな
態度 ; $\beta=0.159, \mathrm{p}<0.01$, ケアの認識の高さ; $\beta=0.131$, $\mathrm{p}<0.01)$ だった。

《前向きな態度》のみに関連した要因は，女性 $(\beta=$ $-0.096, \mathrm{p}<0.01$ ), 学歴 (短大以上) $(\beta=0.061, \mathrm{p}<0.05)$, 現 在の緩和ケア病棟での勤務年数 $(\beta=0.125, \mathrm{p}<0.01)$, 他 の緩和ケア病棟経験あり $(\beta=0.070, \mathrm{p}<0.05)$, ELNEC-J の 修了あり $(\beta=0.065, p<0.05), 6$ 力月間で専門書・杂倠誌を 閲読した冊数の多さ $(\beta=0.150, p<0.01)$, がん・緩和ケア 分野の専門資格者 $(\beta=0.110, \mathrm{p}<0.01)$, 病棟に宗教家あ り $(\beta=0.065, p<0.05)$ ， デスケースカンファレンスの不 定期開催 $(\beta=-0.072, \mathrm{p}<0.05)$, 緩和ケア病棟独自の教育 プログラムあり $(\beta=0.069, \mathrm{p}<0.05)$ だった。

《ケアの認識の高さ》のみに関連したのは, 職位 (主 任以上) $(\beta=0.129, p<0.01)$, 緩和ケア病棟の設立年数が 3 年未満 $(\beta=-0.124, p<0.01)$, 病棟に緩和ケア認定看護 師がいる $(\beta=0.077, p<0.05)$, 患者・家族の創作活動支援 $(\beta=0.114, p<0.01)$ だった。

\section{考 察}

\section{対象者の特徴}

対象は，豊富な看護経験を有していたが，緩和ケア 病棟配属 1〜5 年目が約 $80 \%$ を占めた。がん・緩和ケ アの専門資格者は限られていたが，ELNEC-J 修了者は $53.3 \%$ と半数以上であり, 近年の ELNEC-J 修了者の増 加を反映した。また，専門的緩和ケアの経験者は 46.0\%で，他の緩和ケア病棟や緩和ケア病棟以外の場 等, 多様化しつつあることが示された。

組織因子は，職種やケア内容は施設によるバラッキ がみられた。教育面は, 緩和ケア病棟独自の教育プロ グラムがある施設に所属する看護師は $63.2 \%$ と半数以 上で，事例検討会は $80.5 \%$ が実施し，積極的な教育体 制を示した。

\section{ターミナルケア態度}

ターミナルケア態度の両下位尺度の得点は先行研究 のがん診療連携拠点病院の看護師 ${ }^{21)}$, 訪問看護師等 ${ }^{12)}$ と比較すると, 《前向きな態度》は本調査結果が高かっ たが, 《ケアの認識の高さ》は本調査とほとんど変わら なかった。介護職員対象の調査 ${ }^{22}$ との比較では, 両下 位尺度で, 本調査結果が高かった。一概に他結果と比 較できないが, 緩和ケア病棟の看護師が, 多くの死を 経験する中でも前向きに患者へのケアに取り組んでい る態度が示唆された。

\section{ターミナルケア態度に関連する要因}

両下位尺度に関連した要因は，「緩和ケア病棟への 配属希望あり」(1,088 名中 58.9\%)だった。終末期看護 の関心の高さは積極的な看取りケアに影響することが 示され ${ }^{23)}$, 本研究でも関心の重要性が示された。一方, 


\begin{tabular}{|c|c|c|c|c|c|c|}
\hline & & \multirow{2}{*}{$\mathrm{n}$} & \multicolumn{2}{|c|}{$\begin{array}{l}\text { 1. 死にゆく患者への } \\
\text { ケアの前向きさ1) }\end{array}$} & \multicolumn{2}{|c|}{$\begin{array}{l}\text { 2. 患者·家族を中心 } \\
\text { と多認識) }\end{array}$} \\
\hline & & & $\rho^{3)}$ or mean $\pm \mathrm{SD}^{4)}$ & $p$ value & $\rho^{3)}$ or mean $\pm \mathrm{SD}^{4)}$ & $p$ value \\
\hline \multicolumn{7}{|l|}{ 個人因子 } \\
\hline \multirow[t]{2}{*}{ 性別 } & 男性 & 43 & $59.7 \pm 8.5$ & $\mathrm{p}<0.01$ & $50.4 \pm 4.3$ & $\mathrm{p}=0.64$ \\
\hline & 女性 & 1069 & $62.9 \pm 7.3$ & & $50.1 \pm 4.9$ & \\
\hline 年齢 & & 1104 & $\rho=0.109$ & $\mathrm{p}<0.01$ & $\rho=0.020$ & $\mathrm{p}=0.51$ \\
\hline \multirow[t]{2}{*}{ 学歴 } & 短大以上 & 180 & $64.0 \pm 7.3$ & $\mathrm{p}<0.05$ & $50.2 \pm 4.5$ & $\mathrm{p}=0.61$ \\
\hline & その他 ${ }^{5}$ & 924 & $62.5 \pm 7.4$ & & $50.1 \pm 4.9$ & \\
\hline \multirow[t]{2}{*}{ 看護系教育機関での緩和ケアの授業経験 } & なし & 486 & $62.2 \pm 7.4$ & $\mathrm{p}<0.01$ & $49.7 \pm 5.0$ & $\mathrm{p}<0.05$ \\
\hline & あり & 580 & $63.5 \pm 7.3$ & & $50.4 \pm 4.7$ & \\
\hline \multicolumn{2}{|l|}{ 看護経験年数 } & 1112 & $\rho=0.102$ & $\mathrm{p}<0.01$ & $\rho=0.017$ & $\mathrm{p}=0.57$ \\
\hline \multicolumn{2}{|l|}{ 緩和ケア病棟勤務年数 } & 1112 & $\rho=0.208$ & $\mathrm{p}<0.01$ & $\rho=0.024$ & $\mathrm{p}=0.42$ \\
\hline & なし & 981 & $62.5 \pm 7.4$ & $\mathrm{p}<0.01$ & $50.1 \pm 4.9$ & $\mathrm{p}=0.68$ \\
\hline & あり & 128 & $65.2 \pm 6.6$ & & $50.1 \pm 4.7$ & \\
\hline \multirow[t]{2}{*}{ 職位 } & スタッフ & 959 & $62.5 \pm 7.2$ & $\mathrm{p}<0.01$ & $49.9 \pm 4.8$ & $\mathrm{p}<0.01$ \\
\hline & 主任以上 & 137 & $64.4 \pm 8.0$ & & $51.7 \pm 4.9$ & \\
\hline \multirow[t]{2}{*}{ 緩和ケア病棟への配属希望 } & なし & 447 & $60.9 \pm 7.3$ & $\mathrm{p}<0.01$ & $49.6 \pm 4.9$ & $\mathrm{p}<0.01$ \\
\hline & あり & 641 & $64.2 \pm 7.1$ & & $50.5 \pm 4.8$ & \\
\hline \multirow[t]{2}{*}{ ELNEC-J の修了6) } & なし & 518 & $61.5 \pm 7.3$ & $\mathrm{p}<0.01$ & $49.8 \pm 4.8$ & $\mathrm{p}<0.05$ \\
\hline & あり & 591 & $63.9 \pm 7.3$ & & $50.4 \pm 4.9$ & \\
\hline \multirow[t]{2}{*}{ ELNEC-J 指導者資格 } & なし & 1063 & $62.7 \pm 7.4$ & $\mathrm{p}<0.01$ & $50.1 \pm 4.8$ & $\mathrm{p}=0.64$ \\
\hline & あり & 43 & $66.3 \pm 6.6$ & & $50.4 \pm 5.1$ & \\
\hline \multicolumn{2}{|l|}{$\begin{array}{l}6 \text { カ月間で専門書・雑誌を閲覧した冊数 } \\
\text { の多さ }\end{array}$} & 1064 & $\rho=0.256$ & $\mathrm{p}<0.01$ & $\rho=0.104$ & $\mathrm{p}<0.01$ \\
\hline \multirow{2}{*}{$\begin{array}{l}\text { 専門誌などからの知見の臨床への活用頻 } \\
\text { 度 }\end{array}$} & 低い & 648 & $61.9 \pm 7.2$ & $\mathrm{p}<0.01$ & $49.9 \pm 4.8$ & $\mathrm{p}<0.01$ \\
\hline & 高い & 450 & $64.1 \pm 7.4$ & & $50.6 \pm 4.9$ & \\
\hline \multirow[t]{2}{*}{ がん・緩和ケア分野の専門資格 } & なし & 1042 & $62.4 \pm 7.2$ & $\mathrm{p}<0.01$ & $50.0 \pm 4.8$ & $\mathrm{p}<0.05$ \\
\hline & あり & 70 & $68.7 \pm 7.3$ & & $51.6 \pm 4.7$ & \\
\hline \multicolumn{7}{|l|}{ 組織因子 } \\
\hline \multirow[t]{2}{*}{ 緩和ケア病棟設立からの年数 } & 3 年未満 & 261 & $62.4 \pm 7.2$ & $\mathrm{p}=0.31$ & $51.0 \pm 4.8$ & $\mathrm{p}<0.01$ \\
\hline & 3 年以上 & 851 & $62.9 \pm 7.4$ & & $49.9 \pm 4.8$ & \\
\hline \multirow[t]{2}{*}{ 緩和ケア病棟に緩和ケア認定看護師 } & なし & 88 & $63.8 \pm 6.9$ & $\mathrm{p}=0.30$ & $48.7 \pm 4.1$ & $\mathrm{p}<0.01$ \\
\hline & あり & 782 & $63.0 \pm 7.5$ & & $50.3 \pm 5.0$ & \\
\hline 緩和ケア病棟に通算看護経験 1 年目の看 & なし & 910 & $62.9 \pm 7.4$ & $\mathrm{p}=0.59$ & $50.0 \pm 4.9$ & $\mathrm{p}<0.05$ \\
\hline & あり & 113 & $62.5 \pm 7.2$ & & $51.0 \pm 4.7$ & \\
\hline 緩和ケア病棟に宗教者 & なし & 832 & $62.5 \pm 7.4$ & $\mathrm{p}<0.01$ & $50.1 \pm 4.9$ & $\mathrm{p}=0.69$ \\
\hline & あり & 202 & $64.2 \pm 7.4$ & & $50.2 \pm 4.6$ & \\
\hline 緩和ケア病棟に理学療法士 & なし & 313 & $62.2 \pm 7.4$ & $\mathrm{p}<0.05$ & $49.6 \pm 4.6$ & $\mathrm{p}=0.07$ \\
\hline & あり & 721 & $63.1 \pm 7.4$ & & $50.3 \pm 5.0$ & \\
\hline 緩和ケア病棟にボランティアコーディネ & なし & 485 & $62.4 \pm 7.1$ & $\mathrm{p}<0.05$ & $50.1 \pm 4.8$ & $\mathrm{p}=0.57$ \\
\hline ーター & あり & 365 & $63.4 \pm 7.6$ & & $50.1 \pm 4.9$ & \\
\hline デスケースカンファレンスの開催 & 不定期 & 522 & $63.1 \pm 7.5$ & $\mathrm{p}=0.20$ & $49.9 \pm 5.0$ & $\mathrm{p}=0.10$ \\
\hline & 定期 & 493 & $62.6 \pm 7.4$ & & $50.3 \pm 4.8$ & \\
\hline 提供している専門的緩和ケアの内容 & & & & & & \\
\hline ベッドごとの散歩 & なし & 226 & $61.6 \pm 7.6$ & $\mathrm{p}<0.01$ & $50.0 \pm 5.0$ & $\mathrm{p}=0.60$ \\
\hline & あり & 808 & $63.2 \pm 7.3$ & & $50.1 \pm 4.9$ & \\
\hline 患者·家族の創作活動の支援 & なし & 555 & $62.4 \pm 7.2$ & $\mathrm{p}<0.05$ & $49.7 \pm 4.9$ & $\mathrm{p}<0.05$ \\
\hline & あり & 479 & $63.4 \pm 7.5$ & & $50.5 \pm 4.9$ & \\
\hline ボランティアによる花の水替え & なし & 475 & $62.1 \pm 7.0$ & $\mathrm{p}<0.01$ & $50.1 \pm 5.0$ & $\mathrm{p}=0.98$ \\
\hline & あり & 559 & $63.5 \pm 7.6$ & & $50.1 \pm 4.8$ & \\
\hline ボランティアによるお茶のサービス & なし & 390 & $62.2 \pm 7.5$ & $\mathrm{p}<0.05$ & $50.3 \pm 5.2$ & $\mathrm{p}=0.29$ \\
\hline & あり & 644 & $63.2 \pm 7.3$ & & $50.0 \pm 4.7$ & \\
\hline
\end{tabular}


表 2 (つづき)

\begin{tabular}{|c|c|c|c|c|c|c|}
\hline & & \multirow{2}{*}{$\mathrm{n}$} & \multicolumn{2}{|c|}{$\begin{array}{l}\text { 1. 死にゆく患者への } \\
\text { ケアの前向きさ1) }\end{array}$} & \multicolumn{2}{|c|}{$\begin{array}{l}\text { 2. 患者·家族を中心 } \\
\text { と方認識) }\end{array}$} \\
\hline & & & $\rho^{3)}$ or mean $\pm \mathrm{SD}^{4)}$ & $p$ value & $\rho^{3)}$ or mean $\pm \mathrm{SD}^{4)}$ & $p$ value \\
\hline \multicolumn{7}{|c|}{ 緩和ケア病棟で取り入れている教育方法 } \\
\hline \multirow{2}{*}{ 独自の教育プログラム } & なし & 372 & $62.0 \pm 7.1$ & $\mathrm{p}<0.01$ & $49.7 \pm 4.8$ & $\mathrm{p}=0.21$ \\
\hline & あり & 639 & $63.4 \pm 7.5$ & & $50.3 \pm 5.0$ & \\
\hline \multirow[t]{2}{*}{ 事例検討会 } & なし & 202 & $61.9 \pm 7.1$ & $\mathrm{p}<0.05$ & $50.1 \pm 4.6$ & $\mathrm{p}=0.74$ \\
\hline & あり & 832 & $63.1 \pm 7.5$ & & $50.1 \pm 4.9$ & \\
\hline \multirow[t]{2}{*}{ 院内外の講義 · 講演への参加 } & なし & 18 & $57.7 \pm 7.6$ & $\mathrm{p}<0.01$ & $48.7 \pm 5.8$ & $\mathrm{p}=0.37$ \\
\hline & あり & 1016 & $62.9 \pm 7.4$ & & $50.1 \pm 4.9$ & \\
\hline
\end{tabular}

1）死にゆく患者へのケアの前向きさ range 16-80

2）患者・家族を中心とするケアの認識 range 13-65

3) $\rho:$ Spearman's rank correlation coefficient

4) SD : Standard Deviation

5）その他：高等学校, 高等学校専攻科, 専門・専修を含む

6）ELNEC-J : The End-of-Life Nursing Education Consortium Japanese version コアカリキュラム看護師 教育カリキュラムの略称で，基本的緩和ケアの看護師教育プログラム

\section{表 3 多変量解析 : ターミナルケア態度の 2 つの下位尺度に関連する要因}






\begin{tabular}{|c|c|c|c|c|}
\hline & \multicolumn{2}{|c|}{$\mathrm{n}=908$} & \multicolumn{2}{|c|}{$\mathrm{n}=799$} \\
\hline & \multicolumn{2}{|c|}{$\begin{array}{l}\text { 1. 死にゆく患者への } \\
\text { ケアの前向きさ } \\
\end{array}$} & \multicolumn{2}{|c|}{$\begin{array}{l}\text { 2. 患者·家族を中心 } \\
\text { とするケ認識 } \\
\end{array}$} \\
\hline & $\beta^{1)}$ & $p$ value & $\beta^{1)}$ & $p$ value \\
\hline $\mathrm{R}^{24)}$ & & 0.16 & & 0.07 \\
\hline 調整ずみ $\mathrm{R}^{2}$ & & 0.15 & & 0.06 \\
\hline
\end{tabular}

重回帰分析 (Stepwise 法)

1) $\beta$ : Standard partial regression coefficient

2) その他: 高等学校, 高等学校専攻科, 専門 - 専修を含む

3）ELNEC-J : The End-of-Life Nursing Education Consortium Japanese version コアカリキュラム看護師 教育カリキュラムの略称で, 基本的緩和ケアの看護師教育プログラム

4) $\mathrm{R}^{2}$ : Determination coefficient

緩和ケア病棟配属後，無力感等を感じることが報告さ れ24)，積極的医療から終末期医療への看護観のギャッ プも考えられる。したがって関心の高低がある現状を 理解し，エンパワメントし合えるチーム作りが重要と 考えられる.

《前向きな態度》のみに関連したのは，女性，学歴が 短大卒業以上, 緩和ケア病棟での勤務年数の多さ，他 の緩和ケア病棟経験あり，病棟に宗教家あり，デス ケースカンファレンスの不定期開催，ELNEC-J の修 了, 6 カ月間で専門書・雑誌を閲読した冊数の多さ, がん・緩和ケア分野の資格者, 緩和ケア病棟独自の教 育プログラムの 10 因子だった。

「女性」は, 先行研究の FATCOD 尺度の合計得点に掠 いて関連が報告されており ${ }^{21)}$, 本調査ではケアの前向 きさのみに関連した。

「学歷が短大卒業以上」は, 韓国の研究で修士課程以 上の学歴が関連し ${ }^{25)}$, 一概に比較できないが看護教育 が緩和ケアの理解を深め, ケアの前向きさに影響する 可能性がある.

「緩和ケア病棟での勤務年数の多さ」は, これまでも 経験年数の関連が報告され26)，さらに「他の緩和ケア 病棟経験あり」については, 緩和ケア病棟を変えても 継続的に専門的緩和ケアに携わることが前向きな態度 に関連したと考えられた。しかし，緩和ケア病棟の平 均経験年数は 3.7 年と短く, その原因の一つに, 多く の患者の死から生じる看護師の悲嘆によるバーンアウ 卜が報告され，看護師自身が死生観を深めセルフケア を行う重要性が示唆されており 27 ), 看護師自身のセル フケアや勤務継続を支援する仕組みが重要である。

「病棟に宗教家がいる」ことも前向きな態度に関連し た。緩和ケア病棟での患者の望ましい死の達成度の高 さに，宗教的背景のある施設の関連が報告されてい る ${ }^{28)}$.また, 宗教家はスピリチュアルケアだけでなく, ときにスタッフを支援し，看護師は協働し支持される ことで，前向きな態度に影響したと考えられる。
「デスケースカンファレンスの不定期開催」がより前 向きな態度に関連した。これは医療者間連携の大切さ を実感する機会になる ${ }^{29)}$ が，不定期開催は，倫理的に 問題視した場合等で参加者の関心が高い状態での開催 が考えられ，開催頻度よりも討論の意義が重要と考え られた。

「ELNEC-J の修了」による基本的緩和ケアの知識の獲 得，「6力月間で専門書・雑誌を閲覧した冊数の多さ」 という積極的に学ぶ姿勢が関連した。また、「がん・緩 和ケア分野の資格者」としてキャリアを積む看護師も 前向きな態度に関連した。先行研究でもターミナルケ アの臨床経験や専門資格者は, より前向きな考えが生 じることが示され23), 自発的な学びの姿勢やその継続 性が前向きな態度につながったと考えられる。ささ に,「緩和ケア病棟独自の教育プログラム」による学べ る環境が前向きな態度への支援となったと考えら れる。

《ケアの認識の高さ》にのみ関連したのは, 職位が主 任以上, 病棟に緩和ケア認定看護師がいる, 緩和ケア 病棟設立年数が 3 年未満, 患者・家族の創作活動支援 の 4 因子だった。

「職位」は, 介護職員の先行研究でも関連がみられて おり ${ }^{22)}$ ，十分な看護経験や高い専門性でリーダーシッ プを発揮することが期待されることで, ケアの認識の 高さに関連したと考えた。 また,「病棟に緩和ケア認定 看護師がいる」ことは，専門的緩和ケアのロールモデ ルとして，協働する他の看護師の考え方に影響した可 能性がある。

「緩和ケア病棟設立年数が 3 年未満」が認識の高さに 関連した。廣瀬らの調查では, 緩和ケア病棟設立時の 看護師が次第に自信を持つ過程が報告され ${ }^{30)}$, 病棟創 成期の姿勢がケアの認識の高さに影響したと考えら れる。

「患者・家族の創作活動支援」は，フランスや台湾の 調査で, 創作活動により, がん患者の症状緩和やター 
ミナル期の身体的安楽を得たという報告がある ${ }^{31,32)}$ ， 終末期でも患者は創作による達成感を持ち，家族も気 分転換でき，患者・家族中心のケアの認識の高さにつ ながったと考えられた。

このように，看護師の前向きなターミナルケア態度 に影響する個人・組織因子から，緩和ケア基礎教育の もと，多職種協働の中で専門的緩和ケアに関心をもち 主体的に学び看護観を育む職場環境作りや支持的な継 続教育体制が必要と考えられた。患者・家族中心のケ アの認識を高めて前向きに取り組むために，看護師の 8 割が所属する緩和ケア病棟勤務経験 5 年目以下の現 状を踏まえ, 専門的緩和ケアの経験者や資格者, 役職 者によるリーダーシップやロールモデルが機能するこ とが必要である。さらに, 病棟組織として, がん患 者・家族側の視点でニーズを捉え, 柔軟なターミナル ケアを提供する体制作りの必要性が示唆された。

本調査の限界として，横断調査のため因果関係は特 定できない. 届出認可のない緩和ケア病棟はその実態 把握が困難なため対象に含めていない。また, 調査協 力施設は積極的に取り組む姿勢が考えられ, 調査結果 に影響した可能性がある。さらに，重回帰分析の決定 係数が低く，「過去の看取り件数」「身近な人の看取り 経験」等の，これまでに関連の指摘された要因をいく つか盛り达めなかった影響があるものと考えられる。 今後はそれらの要因や, 職務満足感, 看取りの個人的 な経験等も含めて検討を重ねる必要がある.

\section{結 論}

緩和ケア病棟の看護師のターミナルケア態度の両下 位尺度に関連したのは, 緩和ケア病棟への配属希望と いうターミナルケアへの関心だった，前向きな態度に は，現在の緩和ケア病棟での経験年数，ELNEC-J の修 了，病棟に宗教家がいる，緩和ケア病棟独自の教育プ ログラム等 10 因子が関連した，基本的緩和ケアを基盤 に, 多職種協働の中, 経験を積み専門的緩和ケアの知 識・技術を高めて看護観を深める支持的な教育体制の 必要性が示唆された。さらに, ケアの認識の高さに関 連したのは，患者・家族の創作活動支援等 4 因子で, 緩和ケア病棟内で専門的緩和ケアを充実させる体制の 重要性が示唆された。

謝辞 本調查にご協力頂いた看護師の皆様に心より御礼申し 上げます。また，本調査・論文作成にあたり，終始適切な助言 を賜り, また丁寧にご指導頂いた東京大学大学院医学系研究 科の御子柴直子助教に深く感謝いたします。な抏, 本調查は, 公益財団法人政策医療政策財団の助成のもと実施致しました.
著者の申告すべき利益相反なし

高野は, 研究の構想, デザイン, グラントの申請, 研 究データの収集, 分析, 解釈, 原稿の起草に貢献; 山 花および山本は, 研究の構想, デザイン, 研究デー夕 の収集, 分析, 解釈, 原稿の重要な知的内容に関わる 批判的な推敲に貢献した。すべての著者は投稿論文, 出版原稿の最終承認, および研究の説明責任に同意 した。

\section{文 献}

1）国立がん研究センターがん情報サービス，がん登録・統 計. https://ganjoho.jp/reg_stat/statistics/stat/annual.html (2018 年 6 月 6 日アクセス).

2）国立がん研究センターがん対策情報センター。若尾文 彦，東 尚弘．指標にみるわが国のがん対策．がん対策 に扮ける進捗管理指標の策定と計測システムの確立に 関する研究. 2015. https://www.ncc.go.jp/jp/cis/divisions/ health_s/health_s/020/index.html（2018 年 6 月 6 日アクセ ス).

3）厚生労働省. 3.(1)がんと診断された時からの緩和ケア の推進. 第 3 期 がん対策推進基本計画 2018; 43-49. http://www.mhlw.go.jp/file/06-Seisakujouhou-10900000-Ken koukyoku/0000196975.pdf (2018 年 6 月 6 日アクセス).

4）宮下光令 編. 1 章 緩和ケア概論. 3. 緩和ケアを患者· 家族に提供する方法. ナーシング・グラフィカ 成人看 護学(7) 緩和ケア. メディカ出版. 大阪, 2013; 18-20.

5）厚生労働省．がん等における緩和ケアの更なる推進に 関する検討会における議論の整理. http://www.mhlw. go.jp/file/05-Shingikai-10901000-Kenkoukyoku-Soumuka/ 0000147234.pdf (2018 年 6 月 6 日アクセス).

6）日本ホスピス緩和ケア協会. 緩和ケア病棟入院料 関連 資料. https://hpcj.org/what/aboutpcu.html（2017 年 10 月 6 日アクセス)

7）日本ホスピス緩和ケア協会。緩和ケア病棟自施設評価 結果報告書. https://hpcj.org/med/shiryo.html（2018 年 6 月 6 日アクセス)

8）山田淳子, 野島一彦. ターミナルケアにおける死別後の 悲嘆と対処行動に関する心理学的研究—緩和ケア病棟 の看護婦を対象に. 九州大学心理学研究 2002; 3: 21727.

9）小野充一. 付带研究 心に深く残る体験. 日本ホスピ ス・緩和ケア研究振興財団「遺族によるホスピス・緩和 ケアの質の評価に関する研究」運営委員会編。遺族に よるホスピス・緩和ケアの質の評価に関する研究 3 (J-HOPE3)。日本ホスピス・緩和ケア研究振興財団。東 京, 2016; 174-81.

10）中西美千代, 志自岐康子, 勝野とわ子, 他. ターミナル 期の患者に関わる看護師の態度に関連する要因の検討. 日看科会誌 $2012 ; 32: 40-9$.

11）下西みずえ, 久宗真理, 松井美帆. 心不全終末期患者に 対する看護師の症状マネジメントの実態とターミナル ケア態度に関連する要因. Palliat Care Res 2017; 12: 72330.

12）西尾美登里, 木村裕美. ターミナルにおける看護師の看 
取の満足感に関する研究. 日農村医会誌 2013; 61: 890903.

13）後藤真澄，三上章允，間瀬敬子，他. 高齢者終末期ケア に携わる関係職種の死生観と看取り観について。厚生 の指標 2014; 61: 28-34.

14）大町いづみ, 横尾誠一, 水浦千沙, 他. 一般病院勤務看 護師のターミナルケア態度に関連する要因の分析。保 健学研究 2009; 21: 43-50.

15）国立がん研究センターがん対策情報サービス，緩和ケ ア病棟のある病院を探す. https://hospdb.ganjoho.jp/ kyotendb.nsf/xpPalliativeSearchTop.xsp（2017 年 10 月 6 日 アクセス)

16) Takenouchi S, Miyashita M, Tamura K, et al. Evaluation of the end-of-life nursing education consortium-Japan faculty development program: validity and reliability of the "end-of-life nursing education questionnaire”. J Hosp Palliat Nurs 2011; 13: 368-75.

17) Ferrell B, Malloy P, Virani R. The end of life nursing education nursing consortium project. Ann Palliat Med 2015; 4: 61-9.

18）日本緩和医療学会. ELNEC-Jコアカリキュラム看護師 教育プログラム開催報告. http://www.jspm.ne.jp/elnec/ elnecinfo2011.html (2018 年 6 月 6 日アクセス).

19）中井裕子, 宮下光令, 笹原朋代, 他. Frommelt の夕ー ミナルケア態度尺度日本語版 $(\mathrm{FATCOD} \cdot \mathrm{BJ})$ の因子構造 と信頼性の検討。がん看護 2006; 11: 723-9.

20) Frommelt KHM. The effects of death education on nurses' attitudes toward caring for terminally ill persons and their families. Am J Hosp Palliat Med 1991; 8: 37-43.

21）渡邊清江，遠藤善裕．ターミナル期のがん患者に前向き なケアの考えや感情を有する看護師の傾向。滋賀医科 大学看護学ジャーナル 2015; 13: 39-42.

22）辻麻由美, 田渕康子. 介護職員のターミナルケア態度に 関連する要因の検討一個人属性および死生観との関連
—. Palliat Care Res 2016; 11: 217-24.

23）吉岡さ抢り, 池内香織, 山田苗代, 他. 看護師の末期が ん患者に対する「看取りケア」とそれに関与する要因. 大阪大看誌 2006; 12: 1-10.

24）稲垣久美子, 古澤垔矢子, 村瀬智子，一般病棟での臨床 経験を有する看護師が緩和ケア病棟に配属されて 2 年 未満に経験する心理的負担と対処. 日看科会誌 2016; 36: 41-50.

25) Park KS, Yeom HA. Factors influencing Korean nurses' attitudes towards hospice care. Int Nurs Rev 2014; 61: 563-9.

26) Lange M, Thom B, Kline NE. Assessing nurses' attitudes toward death and caring for dying patients in a comprehensive cancer center. Oncol Nurs Forum 2008; 35: 955-9.

27）藤枝政継，松島英介，上木雅人，他．ホスピスに従事す る看護師の悲嘆とその関連要因バーンアウトとソー シャル・サポートに着目して。緩和医療学 2007; 9: 38795.

28）青山真帆, 斎藤 愛, 菅井真理, 他. 宗教的背景のある 施設において患者の望ましい死の達成度が高い理由一 全国のホスピス・緩和ケア病棟 127 施設の遺族調査の結 果から一. Palliat Care Res 2017; 12: 211-20.

29）角甲 純, 大園康文, 小林成光, 他. がん専門病院の緩 和ケア病棟で行われているデスカンファレンスの内容 分析. Palliat Care Res 2018; 13: 115-20.

30）廣瀬規代美, 中西陽子, 神宮彩子, 他. 初めて緩和ケア 病棟に従事する看護師の問題状況の検討一緩和ケア病 棟開設から 1 年半後までの 3 時点の面接調査一. Palliat Care Res 2017; 12: 771-9.

31) Lefèvre $C$, Ledoux $M$, Filbet $M$. Art therapy among palliative cancer patients: Aesthetic dimensions and impacts on symptoms. Palliat Support Care 2016; 14: 376-80.

32) Lin M-H, Moh S-L, Kuo Y-C, et al. Art therapy for terminal cancer patients in a hospice palliative care unit in Taiwan. Palliat Support Care 2012; 10: 51-7. 


\title{
Original Research
}

\section{Analysis of Factors Related to the Terminal Care Attitudes of Nurses in Palliative Care Units}

\author{
Junko Takano, ${ }^{1)}$ Reiko Yamahana, ${ }^{2)}$ and Noriko Yamamoto-Mitani ${ }^{3)}$ \\ 1) Department of Nurse / Palliative Care Unit, Fujisawa Shounandai Hospital, \\ 2) Department of Gerontological and Home-Care Nursing, Chiba Faculty of Nursing, Tokyo Health Care University, \\ 3) Department of Gerontological Home-Care and Long-term Care Nursing / Palliative Care Nursing, Division of Health Sciences \\ and Nursing, Graduate School of Medicine, The University of Tokyo
}

Purpose: This study aimed to clarify the factors contributing to nurses' attitudes toward terminal care in palliative care units (PCUs). Methods: We conducted a cross-sectional study of nurses in PCUs across Japan using an anonymous self-administered questionnaire, which was mailed to 103 ward managers and 1,671 nurses in PCUs to collect data about nurses' sociodemographic characteristics. Their attitudes towards terminal care were assessed using the Frommelt Attitudes Toward Care of the Dying Scale Form B (Japanese version). Multiple regression analyses were used to identify the factors associated with attitudes towards terminal care. Results: After excluding missing data, valid responses were obtained from 93 ward managers and 1,112 nurses (response rates of $90.3 \%$ and $66.5 \%$, respectively). Based on multivariate analyses, the subdivisions of "positivity of nurses' attitudes toward terminal care" and "high recognition of the patient- and family-centered care" were associated with working in PCUs voluntarily $(\beta=0.159, \beta=0.131, \mathrm{p}<0.01)$. The former subdivision was associated with ten personal factors, including "experience as a nurse in a PCU" $(\beta=0.125, \mathrm{p}<0.01)$, "having a certification of Endof-Life Nursing Education Consortium Japan version Core Curriculum” ( $\beta=0.065, \mathrm{p}<0.05)$. The latter subdivision was associated with four factors enhancing the PCU environment including "support for creative activities of patients and their families" $(\beta=0.114, \mathrm{p}<0.01)$. Conclusion: This study has suggested that gaining the experience at PCUs with multidisciplinary members on a basic palliative care education, a supportive specialized palliative nursing education, and expanding care system in PCUs are important for the positivity of nurses' attitudes toward terminal care.

Palliat Care Res 2018; $13(4): 357-66$

Key words: terminal care attitudes, palliative care unit, nurse 